\title{
Treatment-resistant hypertension
}

\author{
Maja Milošević ${ }^{*}$, Petar Otašević ${ }^{1,2}$ \\ ${ }^{1}$ Dedinje Cardiovascular Institute, Milana Tepića 1, Belgrade 11000, Serbia \\ ${ }^{2}$ University of Belgrade - Faculty of Medicine, Dr Subotića 8, Belgrade 11000, Serbia
}

*Corresponding author: Maja Milošević, e-mail: maja.a.milosevic@gmail.com

\begin{abstract}
Treatment-resistant hypertension is one of the most significant causes of poor blood pressure regulation. Patients with resistant hypertension are at a higher risk of developing comorbidities compared to the general hypertensive population. As a result, these patients have an increased incidence of disability and premature death, as well as increased treatment costs. Due to the above-mentioned, in the last decade, there has been an increase in researchers' interest in elucidating the pathogenesis, diagnosis, and treatment of resistant hypertension. However, recent data indicate that $20 \%$ of female and $24 \%$ of male patients with arterial hypertension still have uncontrolled blood pressure, despite maximum doses of three antihypertensive drugs (including a diuretic) and appropriate lifestyle measures. New treatment modalities (i.e. devicebased interventions - catheter-based renal denervation and baroreceptor stimulation) offer hope for achieving adequate blood pressure regulation in these patients.

In this paper, we have summarized previous knowledge about the mechanisms underlying the pathogenesis of resistant hypertension, as well as optimal diagnostic methods to differentiate true from pseudo-resistant hypertension. We have also given an overview of the current therapeutic approach, including optimal medical therapy and new treatment modalities (i.e. device-based interventions) and their role in the treatment of resistant hypertension.
\end{abstract}

Keywords: true resistant hypertension, pseudo-resistant hypertension, secondary hypertension

doi.org/10.5937/arhfarm72-34248 


\section{Introduction}

Hypertension is the most common chronic non-communicable disease, and recent data show that the number of people aged 30-79 years with hypertension doubled from 1990 to 2019 (1). Among the female hypertensive population, about $59 \%$ of patients have an adequate diagnosis, while the remaining $41 \%$ have no insight into their disease (1). Furthermore, among female patients with arterial hypertension only $47 \%$ are treated and only $23 \%$ have good blood pressure (BP) regulation, while $12 \%$ are not treated and $24 \%$ patients, although treated, still have inadequate BP control (Figure 1). Among male patients with arterial hypertension, $49 \%$ of patients have an adequate diagnosis. Only $38 \%$ of all male hypertensive patients are treated and only $18 \%$ have good BP regulation, while $11 \%$ of patients are diagnosed but not treated, and $20 \%$ of patients are treated but have not achieved adequate BP regulation (Figure 1) (1).

The importance of uncontrolled BP is best illustrated by the fact that about 7 million deaths per year are associated with poor regulation of BP (2). One of the most significant causes of poor BP regulation is resistant hypertension (RH) (2). Patients with $\mathrm{RH}$ are at a higher risk of developing comorbidities compared to the general hypertensive population. As a result, these patients have a poorer prognosis, reflected in an increased incidence of disability and premature death, as well as increased treatment costs (3). Therefore, in addition to its clinical importance, $\mathrm{RH}$ constitutes a considerable public health, economic, and societal burden $(3,4)$. Having in mind all of the above-mentioned, the development of adequate treatment strategies for RH is of great importance.

In this paper, we have summarized previous knowledge about the mechanisms underlying the pathogenesis of resistant hypertension, as well as optimal diagnostic and therapeutic approach for these patients. 


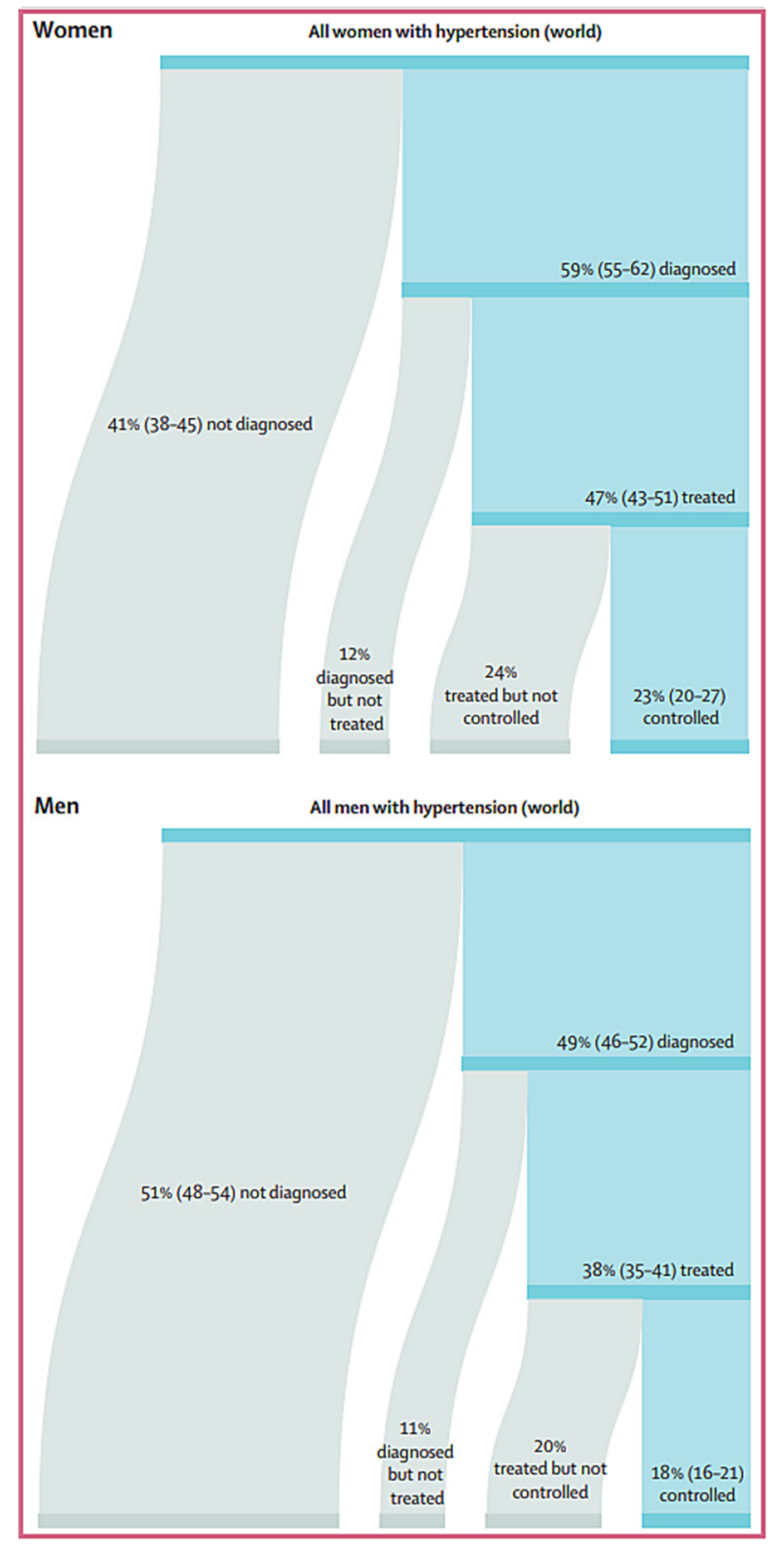

Figure 1. Hypertension treatment cascade in 2019. Adapted from: NCD Risk Factor Collaboration (NCD-RisC). Worldwide trends in hypertension prevalence and progress in treatment and control from 1990 to 2019: a pooled analysis of 1201 population-representative studies with 104 million participants. Lancet. 2021 Sep 11;398(10304):957-980.

Slika 1. Kaskada lečenja hipertenzije u 2019. godini. Modifikovano prema: NCD Risk Factor Collaboration (NCD-RisC). Worldwide trends in hypertension prevalence and progress in treatment and control from 1990 to 2019: a pooled analysis of 1201 population-representative studies with 104 million participants. Lancet. 2021 Sep 11;398(10304):957-980. 


\section{Prevalence}

Recent data indicate that $20 \%$ of female and $24 \%$ of male patients with arterial hypertension have systolic BP values $>140 \mathrm{mmHg}$ and/or diastolic BP values $>90 \mathrm{mmHg}$ despite maximum doses of three antihypertensive drugs (including a diuretic) and appropriate lifestyle measures, which is in accordance with the ESH/ESC (European Society of Hypertension/European Society of Cardiology) definition of resistant hypertension (4). According to the ACC/AHA (American College of Cardiology/American Heart Association) 2008 guidelines, based on the cutoff of 140/90 $\mathrm{mm} \mathrm{Hg}$, the prevalence of resistant hypertension was estimated to be $13 \%$ in the adult population $(5,6)$. However, the 2017 edition of these guidelines suggests stricter BP targets, $<130 / 80 \mathrm{~mm} \mathrm{Hg}$. The current estimates suggest the prevalence is about $4 \%$ higher with this newly recommended control target of $<130 / 80 \mathrm{~mm} \mathrm{Hg}$, which will be subject to validation in future studies (7).

A differentiation of patients with true resistant hypertension from patients with pseudo-resistant hypertension plays a very important role in determining the prevalence of RH (3). A meta-analysis conducted by Noubiap and co-workers, which included 91 studies and more than 3.2 million patients, showed that the prevalence of true resistant hypertension is $10.3 \%$ in the general population of treated patients with hypertension, while the prevalence of pseudo-resistant hypertension is higher - 14\% (3).

Diagnosis of RH is mostly made based on ambulatory blood pressure values, resulting in the inclusion of a great number of patients with white coat hypertension (8, 9). Pseudo-resistant hypertension can also be the result of inaccurate BP measuring techniques, such as the use of an inadequately sized cuff, since the use of a cuff that is too small for the circumference of the arm may result in an overestimation of BP by $>15$ $\mathrm{mmHg}(2)$. However, a far more common cause of pseudo-resistance to antihypertensive drugs is poor treatment adherence (10). Studies that assessed treatment adherence by urine analysis showed that up to $50 \%$ of the patients with apparent resistance were not taking their medication as prescribed $(2,10)$.

\section{Definition}

According to the latest ESH/ESC definition, resistant hypertension is defined as the office systolic BP $>140 \mathrm{mmHg}$ and/or diastolic BP $>90 \mathrm{mmHg}$ despite appropriate lifestyle measures and antihypertensive treatment including diuretic (at full dose) and two other antihypertensive drugs of different classes at an adequate dose (4). As noted above, compared to European guidelines the new ACC/AHA guidelines suggest lower BP targets $<130 / 80 \mathrm{mmHg}$ (7). This definition was later extended to patients in whom BP control was achieved, but required the use of a fourth antihypertensive drug (7). The term refractory hypertension is used when blood pressure control is not achieved despite the use of five or more antihypertensive drugs, including a long-acting thiazide-like diuretic (e.g. chlorthalidone) and a mineralocorticoid receptor antagonist (MRA, i.e. spironolactone) $(7,11)$. 
It is important to note that the above-mentioned definitions of RH do not make a clear distinction between true and pseudo-resistant hypertension. Pseudo-resistant hypertension refers to individuals with ambulatory blood pressure values higher than recommended, as a result of white coat hypertension, inadequate blood pressure measurement or poor treatment adherence (12). Only after ruling out white coat hypertension and confirming the adequacy of blood pressure measurements by $24 \mathrm{~h}$ ambulatory BP measurement (ABPM), as well as confirming patient adherence, can we talk about true RH (12). Therefore, in epidemiological studies, the term "apparent" resistant hypertension is often used to refer to all patients with uncontrolled BP despite drug therapy, and includes both true and pseudo-resistant hypertension (12).

Differentiation of true and pseudo-resistant hypertension is essential for an adequate therapeutic approach to these patients, since patients with true resistant hypertension have a significantly higher risk of macro- and microvascular complications, resulting in a higher incidence of myocardial infarction, congestive heart failure, and chronic kidney disease $(1,13)$.

A prospective study by Salles and co-workers, conducted on 556 patients with $\mathrm{RH}$, showed that patients with RH have two times higher risk of all-cause mortality in addition to higher cardiovascular (CV) risk compared to patients with white coat hypertension (14). This study also showed that higher mean ambulatory BP levels were independent predictors of the composite endpoint (fatal and nonfatal cardiovascular events and allcause and cardiovascular mortality) (14). On the other hand, it has been shown that office $\mathrm{BP}$ values have no prognostic significance (2).

\section{Etiology and pathogenesis}

\section{Risk factors}

The etiology of RH is multifactorial (15). A number of studies have shown that the most common risk factors are older age, chronic kidney disease, and diabetes mellitus (15). It has also been shown that $\mathrm{RH}$ is more common in African Americans than in Caucasians (15). On the other hand, significant factors that are amenable to correction are inadequate lifestyle factors, such as obesity, increased salt intake, and alcohol consumption (16). It has been shown that the modification of the lifestyle risk factors reduces BP values by $5-10 \mathrm{mmHg}$, and also that interventions which involve simultaneous modification of several risk factors are more effective than interventions that include each of these risk factors separately (16).

\section{Excessive sympathetic nervous system activity}

It has been shown that excessive sympathetic nervous system (SNS) activity plays a significant role in the pathogenesis of a number of diseases, such as hypertension, obesity, diabetes mellitus, chronic kidney disease, and obstructive sleep apnea (17-19). Increased SNS activity in patients with hypertension mainly affects the cardiovascular system and kidneys, resulting in the increased release of norepinephrine in these organs 
(17). In these patients, increased noradrenaline production stimulates renal renin production and increased tubular sodium absorption (20). Increased SNS activity also affects the cardiovascular system, causing left ventricular hypertrophy and dysfunction, which may explain the increased incidence of cardiovascular complications in patients with RH (19).

\section{Vascular remodeling}

In patients with $\mathrm{RH}$, vascular remodeling manifested as increased arterial stiffness is likely to be present $(2,21)$. Arterial stiffness of medium-sized arteries is controlled by vasomotor tone and depends on endothelial function, the sympathetic nervous system, and the renin-angiotensin-aldosterone system (RAAS) (21). Studies have shown that arterial stiffness correlates with increased cardiovascular risk and is characteristic of true resistant hypertension (2). The absence of increased arterial stiffness suggests the presence of pseudo-resistance (2). The gold standard method for the noninvasive assessment of arterial stiffness is the measurement of carotid-femoral pulse-wave velocity (PWV) (21). An alternative way to assess arterial stiffness is pulse pressure (PP), defined as the difference between systolic and diastolic blood pressure (21). PWV $>10 \mathrm{~m} / \mathrm{s}$, as well as 24 hour $\mathrm{PP} \geq 63 \mathrm{mmHg}$ or central $\mathrm{PP}>55 \mathrm{mmHg}$, suggest vascular remodeling (2).

\section{Secondary hypertension}

In patients with $\mathrm{RH}$, the prevalence of secondary hypertension is significantly higher compared to the general hypertensive population (17). Secondary hypertension is defined as increased systemic blood pressure due to an identifiable cause (4). Only 5$10 \%$ of patients with arterial hypertension have a secondary form, while the vast majority have essential (idiopathic or primary) hypertension (4). A study by Azizi and co-workers showed that as many as $50 \%$ of the patients with RH have secondary hypertension (22).

Table I shows the most common causes of secondary hypertension. In children and adolescents, the most common causes are renal parenchymal or vascular disease and aortic coarctation (17). In adults, earlier studies have identified renal parenchymal and vascular disease as the most common causes of secondary hypertension, while newer studies point out obstructive sleep apnea as an exceedingly common cause (17). The most common endocrine cause associated with RH is primary aldosteronism, followed by thyroid disease (hypo- or hyperthyroidism), hypercortisolism (Cushing's), and pheochromocytoma (17). 
Table I Overview of the most common causes of secondary hypertension. Adapted from: Secondary arterial hypertension: when, who, and how to screen? Eur Heart J, 2014;35(19):1245-54. BP, blood pressure.

Tabela I Prikaz najčešćih uzroka sekunadrne hipertenzije. Modifikovano prema: Secondary arterial hypertension: when, who, and how to screen? Eur Heart J, 2014;35(19):1245-54.

BP, krvni pritisak.

\begin{tabular}{|c|c|c|c|}
\hline Secondary cause & Prevalence $^{a}$ & Prevalence $^{b}$ & History \\
\hline $\begin{array}{l}\text { Obstructive sleep } \\
\text { apnoea }\end{array}$ & $>5-15 \%$ & $>30 \%$ & $\begin{array}{l}\text { Snoring, daytime sleepiness, morning headach } \\
\text { irritability }\end{array}$ \\
\hline
\end{tabular}

\begin{tabular}{lccl}
\hline $\begin{array}{l}\text { Renal parenchymal } \\
\text { disease }\end{array}$ & $1.6-8.0 \%$ & $2-10 \%$ & $\begin{array}{l}\text { Loss of good BP-control; diabetes; smoking; } \\
\text { generalized atherosclerosis; previous renal failure; } \\
\text { nocturia }\end{array}$ \\
\hline Renal artery stenosis & $1.0-8.0 \%$ & $2.5-20 \%$ & $\begin{array}{l}\text { Generalized atherosclerosis; diabetes; smoking; } \\
\text { recurrent flush pulmonary oedema }\end{array}$ \\
\hline
\end{tabular}

\begin{tabular}{|c|c|c|c|}
\hline $\begin{array}{l}\text { Primary } \\
\text { aldosteronism }\end{array}$ & $1.4-10 \%$ & $6-23 \%$ & Fatigue; constipation; polyuria, polydipsia \\
\hline Thyroid disease & $1-2 \%$ & $1-3 \%$ & $\begin{array}{l}\text { Hyperthyreoidism; palpitations, weight loss, anxiety, } \\
\text { heat intolerance; Hypothyreodism; weight gain, } \\
\text { fatigue, obstipation }\end{array}$ \\
\hline Cushing's Syndrome & $0.5 \%$ & $<1.0 \%$ & $\begin{array}{l}\text { Weight gain; impotence; fatigue; psychological } \\
\text { changes; polydypsia and polyuria }\end{array}$ \\
\hline Phaeochromocytoma & $0.2-0.5 \%$ & $<1 \%$ & Headache; palpitations; flushing; anxiety \\
\hline $\begin{array}{l}\text { Coarctation of the } \\
\text { aorta }\end{array}$ & $<1 \%$ & $<1 \%$ & $\begin{array}{l}\text { Headache; nose bleeding; leg weakness or } \\
\text { claudicatio }\end{array}$ \\
\hline
\end{tabular}

\footnotetext{
${ }^{a}$ Prevalence in hypertensive patients.

${ }^{\mathrm{b}}$ Prevalence in patients with resistant hypertension.
} 


\section{Drugs that may increase blood pressure}

The use of certain drugs has a BP rising effect and may therefore be associated with inadequate BP regulation (23). The most common are non-steroidal anti-inflammatory drugs (NSAIDs) and glucocorticoids. These drugs induce sodium and fluid retention, especially in patients with chronic kidney disease (20). Other drugs that may affect BP regulation are stimulants (e.g. amphetamine, cocaine), adrenal steroids, decongestants (pseudoephedrine), antidepressants (monoamine oxidase inhibitors), antineoplastic (e.g. VEGF-inhibitors) and immunosuppressive drugs (cyclosporin A), as well as some herbal preparations containing ephedra $(4,20,24)$.

\section{Diagnosis}

\section{Clinical evaluation}

Clinical evaluation should be the first step in the diagnosis of resistant hypertension, with the purpose of establishing the diagnosis and grade of hypertension, screening for potential secondary causes of hypertension, identifying factors potentially contributing to the development of hypertension (lifestyle factors, concomitant medications, or family history), identifying concomitant $\mathrm{CV}$ risk factors and concomitant diseases, and establishing whether there is evidence of hypertension-mediated organ damage (HMOD) or existing $\mathrm{CV}$, cerebrovascular, or renal disease (4).

\section{Office blood pressure measurement}

Office blood pressure measurement is usually the next step in diagnosing RH (25). To evade falsely high BP values, which lead to pseudo-resistant hypertension, it is advisable for the patient to avoid physical activity and smoking before the BP measurement (25). The adequate BP measurement techniques, including the adequate size of a cuff, elevation of the arm at a heart level while measuring, repeated measurements on both arms, etc., are of immense importance (25). However, a far more common cause of pseudo-resistant hypertension is white coat hypertension, which is why $24 \mathrm{~h} \mathrm{ABPM}$ is the gold standard method in the diagnosis of $\mathrm{RH}$ (26). In addition, performing $24 \mathrm{~h} \mathrm{ABPM}$ immediately after the patient has taken his/her antihypertensive drugs in the presence of a nurse or physician is an easy way to assess the effect of the prescribed medication (2).

\section{4 hour ambulatory blood pressure measurement}

A detailed approach in the evaluation of patients with suspected resistant hypertension is shown in Figure 2 (2). In all patients in whom resistant hypertension is suspected, i.e. in whom BP pressure values remain $>140$ and/or $90 \mathrm{mmHg}$ despite the use of at least three antihypertensive drugs according to guidelines, $24 \mathrm{~h} \mathrm{ABPM}$ should be performed (2). The importance of $24 \mathrm{~h}$ ABPM is reflected primarily in the exclusion of pseudo-resistant hypertension, which is essential for a further therapeutic approach (26, 27). Given the high prevalence of pseudo-resistant hypertension in patients in whom the 
diagnosis was made based on the office measured BP, the guidelines suggest $24 \mathrm{~h}$ ABPM to be a routine diagnostic modality in these patients (25).

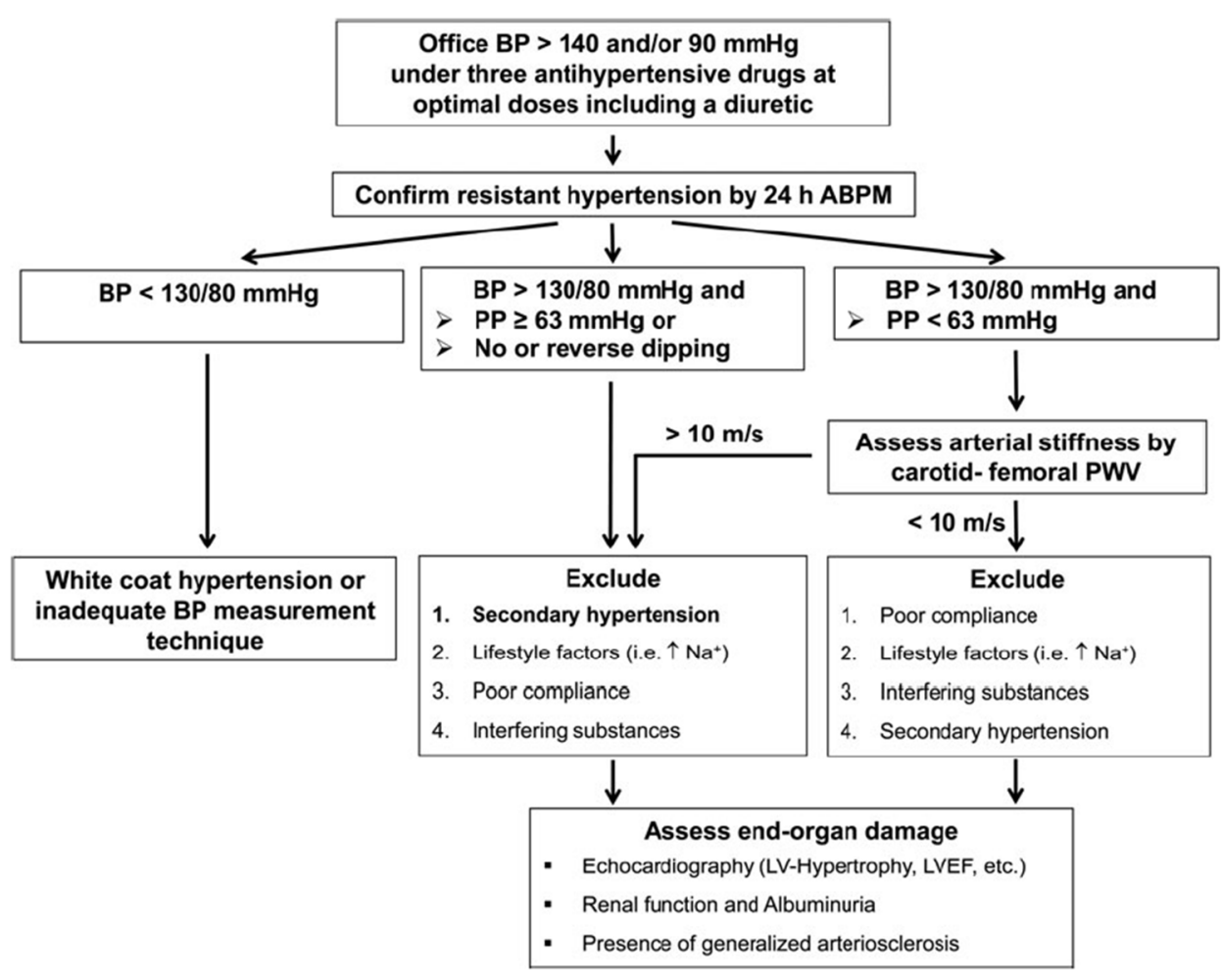

Figure 2. Diagnostic approach in patients with suspected resistant hypertension. Adapted from: Rimoldi SF, Messerli FH, Bangalore S, Scherrer U. Resistant hypertension: what the cardiologist needs to know. Eur Heart J. 2015;36(40):2686-95.

BP, blood pressure; ABPM, ambulatory blood pressure measurement; $\mathrm{Na}+$, sodium; PWV, pulse-wave velocity; PP, pulse pressure.

$L V$, left ventricle; $L V E F$, left ventricular ejection fraction.

Slika 2. Dijagnostički pristup kod pacijenata sa suspektnom rezistentnom hipertenzijom. Modifikovano prema: Rimoldi SF, Messerli FH, Bangalore S, Scherrer U. Resistant hypertension: what the cardiologist needs to know. Eur Heart J. 2015;36(40):2686-95.

KP- krvni pritisak; AMKP - ambulantni monitoring krvnog pritiska; $\mathrm{Na}+$, natrijum; PWV- brzina pulsnog talasa; $\mathrm{PP}$ - pulsni pritisak; LK -leva komora; EFLK - ejekciona frakcija leve komore.

In addition to excluding white coat hypertension, $24 \mathrm{~h}$ ABPM allows the assessment of BP values during the night, which is important in diagnosing secondary hypertension. The absence of a night drop in BP for more than 10\% compared to daily values (nondipping pattern) or an increase in BP during the night (reverse dipping) is often associated 
with secondary hypertension (17). Current evidence suggests that ABPM is a much more accurate predictor of cardiovascular events in resistant hypertension compared to office $\mathrm{BP}$, and can thus offer a better risk stratification for these high-risk individuals. Finally, ABPM offers the potential for a better evaluation of the effect of the conducted pharmacologic and non-pharmacologic therapeutic procedures (26).

\section{Diagnosis of secondary hypertension}

The evaluation of the most common causes of secondary hypertension has a key role in diagnosis of $\mathrm{RH}$ (17). Obstructive sleep apnea should be suspected in the presence of a history of snoring, morning headache, and daytime sleepiness, associated with a nondipping or reverse dipping pattern during $24 \mathrm{~h} \mathrm{ABPM} \mathrm{(28).} \mathrm{Screening} \mathrm{for} \mathrm{the} \mathrm{renal}$ parenchymal disease should begin with a urine analysis (the finding of proteins, erythrocytes and leukocytes) and measuring serum creatinine level. In case of pathological findings, renal ultrasound should be performed (2). Renal artery stenosis should be suspected in case of non-dipping pattern findings during $24 \mathrm{~h} \mathrm{ABPM}$, rapid progression of arterial hypertension, impaired renal function, and recurrent fulminant pulmonary edema (Pickering syndrome). These patients should be screened for renal artery stenosis by ultrasound, computed tomography, or magnetic resonance $(29,30)$.

In patients with a history of fatigue, muscle weakness, polyuria, polydipsia, and constipation primary aldosteronism should be considered (31). The most commonly used parameters for the assessment of primary aldosteronism are plasma renin activity, plasma aldosterone concentration, and aldosterone-renin ratio (31).

\section{Treatment}

Resistant hypertension is almost always multifactorial in etiology. Hence, successful treatment requires the identification and reversal of lifestyle factors contributing to treatment resistance, discontinuation of any BP increasing substances, diagnosis and appropriate treatment of secondary causes of hypertension and the use of effective multidrug regimens $(4,5)$. Lifestyle changes are the first and indispensable step in the treatment of arterial hypertension, as well as RH, and include dietary sodium restriction and other dietary changes, regular physical activity and weight reduction when needed, moderation of alcohol consumption and smoking cessation (4).

\section{Drugs}

The standard approach in the treatment of $\mathrm{RH}$ is shown in Figure 3 (2). 


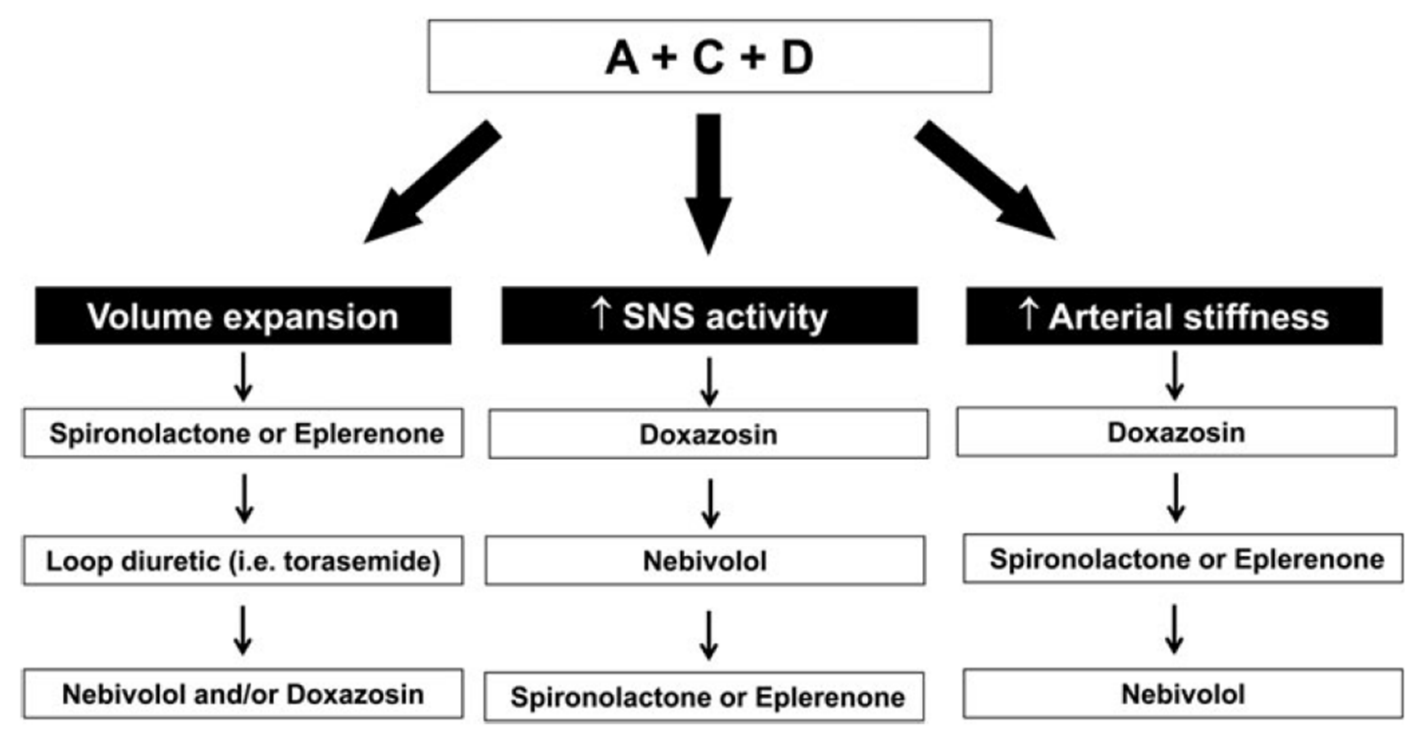

Figure 3. Antihypertensive drug therapy in patients with resistant hypertension. Adapted from: Rimoldi SF, Messerli FH, Bangalore S, Scherrer U. Resistant hypertension: what the cardiologist needs to know. Eur Heart J. 2015;36(40):2686-95.

$A$, angiotensin-converting enzyme inhibitor or angiotensin II receptor antagonist; $C$, calcium channel blocker; D, thiazide(-like) diuretics; SNS, sympathetic nervous system.

Slika 3. Medikamentna terapija rezistentne hipertenzije. Modifikovano prema: Rimoldi SF, Messerli FH, Bangalore S, Scherrer U. Resistant hypertension: what the cardiologist needs to know. Eur Heart J. 2015;36(40):2686-95. A, inhibitori angiotenzin konvertujućeg enzima ili antagonisti angiotenzin II receptora; C, blokatori kalcijumskih kanala; D, tiazidu-slični diuretici; SNS, simpatički nervni sistem.

As recommended by the guidelines, the first step in optimizing drug therapy should be a combination of A (angiotensin-converting enzyme inhibitor - ACEI or angiotensin II receptor antagonist - ARB) + C (calcium channel blocker - CCB) + D (thiazide-like diuretic i.e. chlortalidone or indapamide), in the maximum tolerable dose $(32,33)$. The idea of combined therapy is based on the assumption that a larger number of drugs, which act on different pathophysiological mechanisms underlying hypertension, will have a greater effect on BP lowering than monotherapy (34). Furthermore, the combination of antihypertensive drugs reduces the variability in blood pressure values (34). It is suggested that single-pill combinations of $\mathrm{A}+\mathrm{C}+\mathrm{D}$ should be used whenever possible, as these combinations are more effective in lowering BP, have a better adverse effect profile, and improve therapy adherence $(35,36)$.

In patients with moderate impairment of renal function (i.e. glomerular filtration rate $(\mathrm{GFR}) \leq 45 \mathrm{~mL} / \mathrm{min})$, both thiazides and thiazide-like agents are less effective, and 
become ineffective when the eGFR $<30 \mathrm{ml} / \mathrm{min}$. In such circumstances, loop diuretics such as furosemide (or torasemide) should replace thiazides and thiazide-like diuretics to achieve an antihypertensive effect $(4,37)$.

Although $\mathrm{C}$ strategy is often based on dihydropyridine CCBs (i.e. amlodipine, felodipine, lercanidipine, and nifedipine), in some cases (such as increased heart rate) non-dihydropyridine CCBs (i.e. verapamil and diltiazem) should be considered (2).

The second step involves the clinical evaluation of patients who are still hypertensive despite the use of three antihypertensive drugs to detect the prevailing pathogenic mechanism (2). Increased sodium and water retention is manifested through peripheral edema, increased urinary sodium excretion, and increased left ventricular filling pressures (38). In patients with increased heart rate, the most common mechanism is increased sympathetic activation (39). On the other hand, PWV $>10 \mathrm{~m} / \mathrm{s}$, as well as values of $24 \mathrm{~h}$ measured peripheral $\mathrm{PP} \geq 63 \mathrm{mmHg}$ or central $\mathrm{PP}>55 \mathrm{mmHg}$ indicate increased arterial stiffness (39).

The third step includes the addition of a fourth-line antihypertensive drug, depending on the predominant pathophysiological mechanism (2). In patients with increased sodium and water retention MRA (i.e. spironolactone or eplerenone) is recommended $(38,40,41)$. In case of increased SNS activity and/or increased arterial stiffness, it is recommended to include an alpha-blocker (i.e. doxazosin), which may have a beneficial effect on both BP regulation and vascular remodeling (39).

The PATHWAY-2 study showed the superiority of spironolactone (25-50 mg) in comparison to the placebo, bisoprolol (5-10 mg), and doxazosin (4-8 mg) in the treatment of resistant hypertension (42). The most common side effect of spironolactone is hyperkalemia, which can be resolved by reducing the dose of spironolactone, adding or increasing the dose of a thiazide or thiazide-like diuretic, or possibly adding a Henle loop diuretic. If hyperkalemia persists, administration of amiloride (10-20 mg/day), which has a lower potential for hyperkalemia, should be considered $(4,43)$. The use of spironolactone for resistant hypertension should be restricted to patients with an eGFR $>$ > $45 \mathrm{~mL} / \mathrm{min}$ and a plasma potassium concentration of $<4.5 \mathrm{mmol} / \mathrm{L} \mathrm{(4)}$.

Another significant spironolactone side effects are anti-androgenic and progestational effects, which primarily include painful breast tenderness and gynecomastia (43). These side effects are dose-dependent and in most cases reversible after discontinuation of the drug. In the case of anti-androgenic side effects, spironolactone may be replaced by amiloride or eplerenone $(50-100 \mathrm{mg} /$ day $)(4,43)$.

As mentioned, the PATHWAY-2 study also evaluated bisoprolol or doxazosin modified release as alternatives to spironolactone. Although neither was as effective as spironolactone, they did reduce BP significantly in comparison to placebo when added to background treatment in resistant hypertension $(4,24)$. Thus, bisoprolol and doxazosin have an evidence base for the treatment of resistant hypertension when spironolactone is contraindicated or not tolerated (4). 


\section{Device-based interventions in the treatment of resistant hypertension}

Device-based interventions, including carotid baroreceptor stimulation and catheter renal denervation (RDN), should be considered in patients who remain hypertensive despite an optimal A $+\mathrm{C}+\mathrm{D}$ plus MRA strategy (Figure 4) $(2,44)$. Although both procedures have the same goal - reducing blood pressure by suppressing excessive SNS activity, there are some basic differences in the mechanism of their action. Carotid baroreceptor stimulation achieves central regulation of the SNS through electrical activation of this sympatho-inhibitory reflexogenic area, while RDN, on the other hand, decreases sympathetic over-activity by ablation of renal sympatho-excitatory afferents (44). Moreover, carotid baroreceptor stimulation significantly decreases resting heart rate, whereas RDN has no such effect (44).

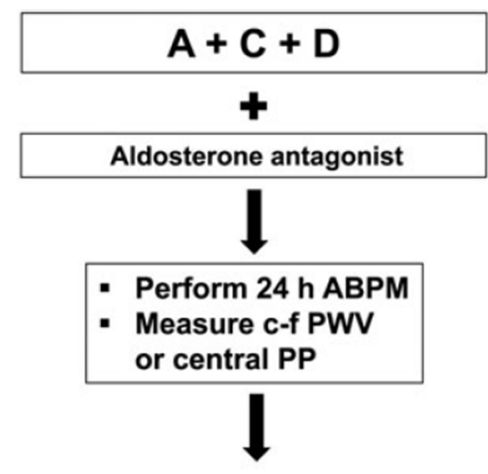

Isolated systolic hypertension and / or

$\uparrow$ Arterial stiffness (i.e. PWV $>10 \mathrm{~m} / \mathrm{s}$ or $24 \mathrm{~h}$ PP $>63 \mathrm{mmHg}$, or central PP > $55 \mathrm{mmHg}$ )

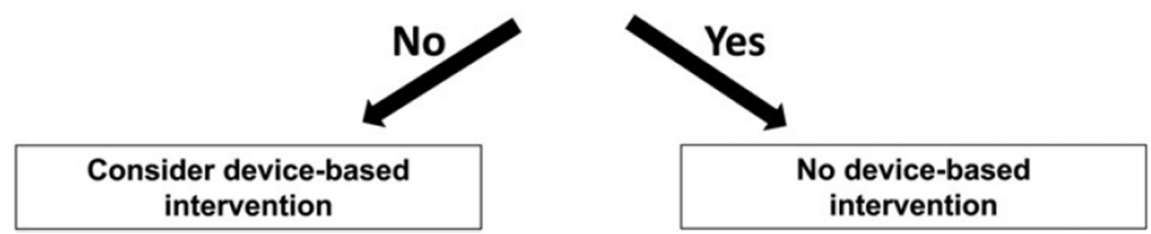

Figure 4. Screening for device-based interventions. Adapted from: Rimoldi SF, Messerli FH, Bangalore S, Scherrer U. Resistant hypertension: what the cardiologist needs to know. Eur Heart J. 2015;36(40):2686-95.

$A$, angiotensin-converting enzyme inhibitor or angiotensin II receptor antagonist; C, calcium channel blockers; D, thiazide(-like) diuretics; ABPM, ambulatory blood pressure measurement; PWV, pulse-wave velocity; PP, pulse pressure.

Slika 4. Skrining pacijenata sa rezistentnom hipertenzijom za primenu novih modaliteta lečenja. Modifikovano prema: Rimoldi SF, Messerli FH, Bangalore S, Scherrer U. Resistant hypertension: what the cardiologist needs to know. Eur Heart J. 2015;36(40):2686-95.

A, inhibitori angiotenzin konvertujućeg enzima ili antagonisti angiotenzin II receptora; C, blokatori kalcijumskih kanala; D, tiazidu-slični diuretici; ABPM, ambulatorni monitoring krvnog pritiska; PWV, brzina pulsnog talasa; PP, pulsni pritisak. 
Figure 4 shows a screening procedure for device-based interventions (2). Patients remaining hypertensive under therapy with the combination $\mathrm{A}+\mathrm{C}+\mathrm{D}$ plus MRA should undergo $24 \mathrm{~h} \mathrm{ABPM}$ and arterial stiffness assessment. Studies have shown that isolated systolic hypertension (ISH) and increased arterial stiffness are negative predictors of efficacy, and device-based interventions should therefore not be performed in those patients $(45,46)$.

\section{Renal catheter denervation}

The principle of RDN in the treatment of $\mathrm{RH}$ is based on the knowledge that renal sympathetic fibers have a significant effect on renin release, salt and water retention, and regulation of blood flow through the kidneys, which plays a significant role in the pathogenesis of hypertension (44). Due to the connection of renal afferent and efferent sympathetic pathways, ablation of afferent fibers can reduce central sympathetic drive. As a result, local but also systemic reduction of sympathetic stimulation is achieved (44).

The RDN procedure involves femoral artery catheterization, followed by the application of radiofrequency (RF) energy to the endothelial lining (44). Recently, an alternative technology has been developed, which delivers ultrasound energy to thermally ablate the renal sympathetic nerves (47).

The RADIANCE-HTN SOLO and SPYRAL HTN-OFF MED trials enrolled large patient populations and yielded consistent results, showing the BP lowering effect of RDN compared with a sham control, in patients who were off antihypertensive medications. Moreover, it has been suggested that endovascular ultrasound-based RDN decreases ambulatory BP to a greater extent than radiofrequency-based ablation $(47,48)$.

\section{Carotid baroreceptor stimulation}

Carotid baroreceptors are located in the aortic arch and carotid sinus, at the carotid bifurcation. Their role is to provide afferent signals to the medulla, as a part of the negative feedback loop that maintains mean arterial pressure (MAP) within physiological limits. An increase in MAP causes baroreceptor stimulation, which leads to a decrease of sympathetic stimulation on peripheral blood vessels and the heart. This causes vasodilation and reduced cardiac output, consequently causing a decrease in MAP (49). Device-based carotid baroreceptor stimulation, which involves bilateral surgical implantation of electrical stimulators at the level of the carotid sinus, acts through this physiological mechanism, causing a decrease in MAP (50). The results of a study by Heusser and co-workers showed that carotid baroreceptor stimulation in patients with RH reduced blood pressure by $10 / 6 \mathrm{mmHg}$ (50). On the other hand, the disadvantages of this procedure include its invasiveness and limited efficacy in patients with primary hyperaldosteronism $(2,50)$. 


\section{Conclusion}

Resistant hypertension is a common health, economic and societal problem, causing increased morbidity, mortality, and reduced quality of life. In the last decade, there has been an increase in researchers' interest in elucidating the pathogenesis, diagnosis, and treatment of resistant hypertension. Nevertheless, data regarding the optimal treatment of these patients are still limited. Therefore, further studies to address this topic are needed.

\section{References}

1. NCD Risk Factor Collaboration (NCD-RisC). Worldwide trends in hypertension prevalence and progress in treatment and control from 1990 to 2019: a pooled analysis of 1201 populationrepresentative studies with 104 million participants. Lancet. 2021;398(10304):957-980.

2. Rimoldi SF, Messerli FH, Bangalore S, Scherrer U. Resistant hypertension: what the cardiologist needs to know. Eur Heart J. 2015;36(40):2686-95.

3. Noubiap JJ, Nansseu JR, Nyaga UF, Sime PS, Francis I, Bigna JJ. Global prevalence of resistant hypertension: a meta-analysis of data from 3.2 million patients. Heart. 2019;105(2):98-105.

4. Williams B, Mancia G, Spiering W, Agabiti Rosei E, Azizi M, Burnier M, et al. 2018 ESC/ESH Guidelines for the management of arterial hypertension: The Task Force for the management of arterial hypertension of the European Society of Cardiology (ESC) and the European Society of Hypertension (ESH). Eur Heart J. 2018;39(33):3021-3104.

5. Calhoun DA, Jones D, Textor S, Goff DC, Murphy TP, Toto RD, et al. Resistant hypertension: diagnosis, evaluation, and treatment: a scientific statement from the American Heart Association Professional Education Committee of the Council for High Blood Pressure Research. Hypertension. 2008;51:1403-19.

6. Achelrod D, Wenzel U, Frey S. Systematic review and meta-analysis of the prevalence of resistant hypertension in treated hypertensive populations. Am J Hypertens. 2015;28:355-61.

7. Whelton PK, Robert MC, Aronow WS, Casey DE, Collins KJ, Dennison Himmelfarb C, et al. 2017 ACC/AHA/AAPA/ABC/ACPM/AGS/APhA/ASH/ASPC/NMA/PCNA Guideline for the Prevention, Detection, Evaluation, and Management of High Blood Pressure in Adults: A Report of the American College of Cardiology/American Heart Association Task Force on Clinical Practice Guidelines. Hypertension. 2018;71(6):e13-e115.

8. Smith SM. Epidemiology, Prognosis, and Treatment of Resistant Hypertension. Pharmacotherapy. 2013;33(10):1071-86.

9. de la Sierra A, Segura J, Banegas JR, Gorostidi M, de la Cruz JJ, Armario P, et al. Clinical features of 8295 patients with resistant hypertension classified on the basis of ambulatory blood pressure monitoring. Hypertension. 2011;57(5):898-902.

10. Jung O, Gechter JL, Wunder C, Paulke A, Bartel C, Geiger H, et al. Resistant hypertension? Assessment of adherence by toxicological urine analysis. J Hypertens. 2013;31(4):766-74.

11. Acelajado MC, Hughes ZH, Oparil S, Calhoun DA. Treatment of Resistant and Refractory Hypertension. Circ Res. 2019;124(7):1061-1070. 
12. Hayek SS, Abdou MH, Demoss BD, Legaspi JMO, Veledar E, Deka A, et al. Prevalence of resistant hypertension and eligibility for catheter-based renal denervation in hypertensive outpatients. Am J Hypertens. 2013;26(12):1452-8.

13. Cuspidi C, Macca G, Sampieri L, Michev I, Salerno M, Fusi V, et al. High prevalence of cardiac and extracardiac target organ damage in refractory hypertension. J Hypertens. 2001;19(11):2063-70.

14. Salles GF, Cardoso CR, Muxfeldt ES. Prognostic influence of office and ambulatory blood pressures in resistant hypertension. Arch Intern Med. 2008;168(21):2340-6.

15. Calhoun DA. Hyperaldosteronism as a Common Cause of Resistant Hypertension. Annu Rev Med. 2013;64:233-47.

16. Jordan J, Yumuk V, Schlaich M, Nilsson PM, Zahorska-Markiewicz B, Grassi G, et al. Joint statement of the European Association for the Study of Obesity and the European Society of Hypertension: obesity and difficult to treat arterial hypertension. J Hypertens. 2012;30(6):1047-55.

17. Hwang AY, Dietrich E, Pepine CJ, Smith SM. Resistant Hypertension: Mechanisms and Treatment. Curr Hypertens Rep. 2017 Jul;19(7):56.

18. Grassi G, Mark A, Esler M. The sympathetic nervous system alterations in human hypertension. Circ Res. 2015;116(6):976-90.

19. Grassi G, Bombelli M, Buzzi S, Volpe M, Brambilla G. Neuroadrenergic disarray in pseudo-resistant and resistant hypertension. Hypertens Res. 2014;37(6):479-83.

20. Rimoldi SF, Scherrer U, Messerli FH. Secondary arterial hypertension: when, who, and how to screen? Eur Heart J. 2014;35(19):1245-54.

21. Boutouyrie P, Fliser D, Goldsmith D, Covic A, Wiecek A, Ortiz A, et al. Assessment of arterial stiffness for clinical and epidemiological studies: methodological considerations for validation and entry into the European Renal and Cardiovascular Medicine registry. Nephrol Dial Transplant. 2014;29(2):232-9.

22. Azizi M, Sapoval M, Gosse P, Monge M, Bobrie G, Delsart P, et al. Optimum and stepped care standardized antihypertensive treatment with or without renal denervation for resistant hypertension (DENERHTN): a multicentre, open-label, randomised controlled trial. Lancet. 2015;385(9981):1957-65.

23. Grossman E, Messerli FH. Drug-induced hypertension: an unappreciated cause of secondary hypertension. Am J Med. 2012;125(1):14-22.

24. Salerno SM, Jackson JL, Berbano WP. Effect of oral pseudoephedrine on blood pressure and heart rate: a meta-analysis. Arch Intern Med. 2005;165(15):1686-94.

25. Sarafidis PA, Bakris GL. Resistant Hypertension: An Overview of Evaluation and Treatment. J Am Coll Cardiol. 2008;52(22):1749-57.

26. Pena-Hernandez C, Nugent K, Tuncel M. Twenty-Four-Hour Ambulatory Blood Pressure Monitoring. J Prim Care Community Health. 2020;11:1-8.

27. Lazaridis AA, Sarafidis PA, Ruilope LM. Ambulatory Blood Pressure Monitoring in the Diagnosis, Prognosis, and Management of Resistant Hypertension: Still a Matter of our Resistance? Curr Hypertens Rep. 2015;17(10):78.

28. Fletcher EC. Sympathetic over activity in the etiology of hypertension of obstructive sleep apnea. Sleep. 2003:26(1):15-9. 
29. Baumgartner I, Lerman LO. Renovascular hypertension: screening and modern management. Eur Heart J. 2011;32(13):1590-8.

30. Messerli FH, Bangalore S, Makani H, Rimoldi SF, Allemann Y, White CJ, et al. Flash pulmonary oedema and bilateral renal artery stenosis: the Pickering syndrome. Eur Heart J. 2011;32(18):2231-5.

31. Rossi GP, Bernini G, Caliumi C, Desideri G, Fabris B, Ferri C, et al. A prospective study of the prevalence of primary aldosteronism in 1,125 hypertensive patients. J Am Coll Cardiol. 2006;48(11):2293-300.

32. Fagard RH. Resistant hypertension. Heart. 2012;98(3):254-61.

33. James PA, Oparil S, Carter BL, Cushman WC, Dennison-Himmelfarb C, Handler J, et al. 2014 evidence-based guideline for the management of high blood pressure in adults: report from the panel members appointed to the Eighth Joint National Committee (JNC 8). JAMA. 2014;311(5):507-20.

34. Sever PS, Messerli FH. Hypertension management 2011: optimal combination therapy. Eur Heart J. 2011;32(20):2499-506.

35. Mourad JJ, Amodeo C, de Champvallins M, Brzozowska-Villatte R, Asmar R. Blood pressurelowering efficacy and safety of perindopril/indapamide/amlodipine single-pill combination in patients with uncontrolled essential hypertension: a multicenter, randomized, double-blind, controlled trial. J Hypertens. 2017;35(7):1481-1495.

36. Gupta AK, Arshad S, Poulter NR. Compliance, safety, and effectiveness of fixeddose combinations of antihypertensive agents: a meta-analysis. Hypertension. 2010;55(2):399-407.

37. Kramer HJ, Townsend RR, Griffin K, Flynn JT, Weiner DE, Rocco MV, et al. KDOQI US Commentary on the 2017 ACC/AHA Hypertension Guideline. Am J Kidney Dis. 2019 Apr;73(4):437-458.

38. Vaclavik J, Sedlak R, Plachy M, Navratil K, Plasek J, Jarkovsky J, et al. Addition of spironolactone in patients with resistant arterial hypertension (ASPIRANT): a randomized, double-blind, placebocontrolled trial. Hypertension. 2011;57(6):1069-75.

39. Chapman N, Chen CY, Fujita T, Hobbs FD, Kim SJ, Staessen JA, et al. Time to re-appraise the role of alpha-1 adrenoceptor antagonists in the management of hypertension? $\mathrm{J}$ Hypertens. 2010;28(9):1796-803.

40. Yugar-Toledo JC, Modolo R, Faria AP, Moreno H. Managing resistant hypertension: focus on mineralocorticoid-receptor antagonists. Vasc Health Risk Manag. 2017;13:403-411.

41. Dudenbostel T, Calhoun DA. Use of Aldosterone Antagonists for Treatment of Uncontrolled Resistant Hypertension. Am J Hypertens. 2017;30(2):103-109.

42. Williams B, MacDonald TM, Morant S, Webb DJ, Sever P, McInnes G, et al. Spironolactone versus placebo, bisoprolol, and doxazosin to determine the optimal treatment for drug-resistant hypertension (PATHWAY-2): a randomised, double-blind, crossover trial. Lancet. 2015;386(10008):2059-2068.

43. Rosa J, Zelinka T, Petrák O, Štrauch B, Holaj R, Widimský Jr J. Should All Patients with Resistant Hypertension Receive Spironolactone? Curr Hypertens Rep. 2016;18(11):81.

44. Krum H, Schlaich M, Sobotka P, Scheffers I, Kroon AA, de Leeuw PW. Novel procedure- and device-based strategies in the management of systemic hypertension. Eur Heart J. 2011 32(5):537-44.

45. Ewen S, Ukena C, Linz D, Kindermann I, Cremers B, Laufs U, et al. Reduced effect of percutaneous renal denervation on blood pressure in patients with isolated systolic hypertension. Hypertension. 2015;65(1):193-9. 
46. von Arx R, Rexhaj E, Allemann Y, Moschovitis A, Windecker S, Meier B, et al. Lack of blood pressure-lowering effect of renal denervation in a drug-naive patient with pronounced arterial stiffening. Am J Med. 2014;127(9):e3-4.

47. Azizi M, Schmieder RE, Mahfoud F, Weber MA, Daemen J, Lobo MD. Six-Month Results of Treatment-Blinded Medication Titration for Hypertension Control Following Randomization to Endovascular Ultrasound Renal Denervation or a Sham Procedure in the RADIANCE-HTN SOLO Trial. Circulation. 2019;139:2542-2553.

48. Townsend RR, Mahfoud F, Kandzari DE, Kario K, Pocock S, Weber MA. Catheter-based renal denervation in patients with uncontrolled hypertension in the absence of antihypertensive medications (SPYRAL HTN-OFF MED): a randomised, sham-controlled, proof-of-concept trial. Lancet. 2017;390(10108):2160-2170.

49. Kougias P, Weakley SM, Yao Q, Lin PH, Chen C. Arterial baroreceptors in the management of systemic hypertension. Med Sci Monit. 2010;16(1):RA1-RA8.

50. Heusser K, Tank J, Engeli S, Diedrich A, Menne J, Eckert S, et al. Carotid baroreceptor stimulation, sympathetic activity, baroreflex function, and blood pressure in hypertensive patients. Hypertension. 2010;55:619-626. 


\title{
Rezistentna hipertenzija
}

\author{
Maja Milošević ${ }^{{ }^{*}}$, Petar Otašević ${ }^{1,2}$ \\ ${ }^{1}$ Institut za kardiovaskularne bolesti Dedinje, Milana Tepića 1, Beograd, 11000, Srbija \\ ${ }^{2}$ Univerzitet u Beogradu - Medicinski fakultet, Dr Subotića 8, Beograd, 11000, Srbija
}

*Autor za korespondenciju: Maja Milošević, e-mail: maja.a.milosevic@gmail.com

\section{Kratak sadržaj}

Rezistentna hipertenzija je jedan od najznačajnijih uzroka loše regulacije krvnog pritiska. Pacijenti sa rezistentnom hipertenzijom imaju veći rizik od razvoja komorbiditeta u poređenju sa opštom hipertenzivnom populacijom. Kao rezultat toga, ovi pacijenti imaju veću učestalost invalidnosti i prerane smrti, kao i povećane troškove lečenja. Zbog svega navedenog, u prošloj deceniji došlo je do porasta interesovanja istraživača za proučavanje patogeneze, dijagnoze i lečenja rezistentne hipertenzije. Međutim, najnoviji podaci ukazuju da $20 \%$ žena i $24 \%$ muškaraca sa arterijskom hipertenzijom i dalje ima lošu regulaciju krvnog pritiska, uprkos maksimalnim dozama tri antihipertenzivna leka (uključujući diuretik) i odgovarajućem stilu života. Novi modaliteti lečenja (renalna kateterska denervacija i stimulacija baroreceptora) pružaju nadu za postizanje adekvatne regulacije krvnog pritiska kod ovih pacijenata.

U ovom radu sumirali smo dosadašnja saznanja o mehanizmima koji su u osnovi patogeneze rezistentne hipertenzije, kao i optimalnim dijagnostičkim metodama za diferenciranje prave od pseudo-rezistentne hipertenzije. Takođe smo dali pregled aktuelnih terapijskih pristupa, uključujući optimalnu medikamentnu terapiju i nove modalitete lečenja, kao i njihove uloge u lečenju rezistentne hipertenzije.

Ključne reči: stvarna rezistentna hipertenzija, pseudo-rezistentna hipertenzija, sekundarna hipertenzija 